\title{
Systematic Mapping of Scientific Production on Open Innovation (2015-2018): Opportunities for Sustainable Training Environments
}

\author{
Abel García-González *(D) and María-Soledad Ramírez-Montoya \\ School of Humanities and Education, Tecnologico de Monterrey, 64849 Monterrey, Mexico; solramirez@tec.mx \\ * Correspondence: abelgar.g@gmail.com
}

Received: 8 December 2018; Accepted: 12 February 2019; Published: 25 March 2019

\begin{abstract}
Open innovation presents data that may be of value for future research and empirical studies in sustainable training environments. This paper aims to analyze the evidence published in the last three years (2015-2018) regarding open innovation, in order to identify the publications on the subject that may contribute to other studies or practical experiences. The systematic mapping method was used, reviewing 104 articles published from January 2015 to September 2018, which included studies on open innovation that were published in two databases-Web of Science (WOS) and Scopus. Inclusion, exclusion and quality criteria were applied in order to obtain the most relevant information. Findings show the type of methodology used, the most cited articles, the journals where they were published, the geographical distribution of the authors, the area of influence, contexts of application and the topics addressed. This paper provides value to assess progress, identify challenges and contexts of less influence, as well as to establish a database of scientific studies as support for future research.
\end{abstract}

Keywords: open innovation; sustainability; training environments; systematic mapping

\section{Introduction}

Sustainability is an underlying concern among different sectors, such as the social, business, cultural and academic sectors. In the educational area, specifically, the 2030 Agenda proposed by UNESCO states in its Sustainable Development Goal 4 that inclusive and equal quality education should be ensured, and permanent learning opportunities should be fostered for everyone [1]. In this search, new opportunities to generate knowledge may contribute to these purposes, and furthermore, to the concept of open innovation. According to the Organization for Economic Co-operation and Development (OECD), the term open innovation was coined by Chesbrough in 2003, who defines it as an innovation model which is characterized as being dynamic and based on knowledge [2]. It can be said that open innovation is an innovation model comprising the generation and transference of knowledge by means of collaboration networks both in and outside organizations, aiming to help improve the products and services they offer to be more competitive.

Open innovation is characterized by the free transference of knowledge between the different subjects involved, such as universities, companies and the government. Open innovation is characterized as the new imperative to create and take advantage of technology, which assumes that an organization can improve its innovative abilities by means of interacting with other organizations [3]. In addition, it involves helping internal innovation of companies using knowledge input and output using technologies and aiming to expand their markets and become more competitive [4-6]. Therefore, its classification is the following: from outside to inside and from inside to outside innovation [7] and even the combination of internal and external processes [8], and it can be integrated according to the 
business model, technologies, knowledge management and intellectual property [9]. Although open innovation is more closely related to the business sector, its expansion is also taking place in other sectors, such as the academic sector.

In open innovation, collaboration is important, since it allows for co-production. Some authors claim that open innovation is co-produced, which means that some share ideas or resources and others use technology to set the innovation project in motion $[10,11]$. To increase knowledge, open innovation requires the collaboration of other subjects such as universities, companies and the government [12]. Moreover, it requires taking into account that intellectual capital adds to useful knowledge that may be transformed into value [13]. Collaboration in open innovation has been emphasized since it allows the formation of alliances that offer external knowledge, fosters research and shows indirect strategic, economic and political benefits [14]. Innovation is strengthened by collaboration, and if different experts are involved in the collaboration, open innovation should have better possibilities to expand.

To achieve open innovation, it is necessary to integrate multidisciplinary teams since an organization's improvement is only achieved by passing through disciplines. Multidisciplinary innovation is defined as the result of the collaborative work of a group of experts. It is also called 'innovation network' [15], 'hybrid innovation' [16], 'multidisciplinary innovation teams' [17], 'different professional groups in a team' [18], 'different disciplinary approaches' [19]. Multidisciplinary innovation reflects the collaboration and cooperation practice of different disciplines, methods and, approaches, fostering multi-institutional learning with experts having different training backgrounds [20]. In this manner, multidisciplinary innovation is presented as a type of innovation which is developed from the involvement of a group of experts that create knowledge networks through collaboration to address an issue and generate options for sustainable development.

Sustainability represents a challenge to create new options for the training environments and open innovation may contribute to some possibilities. Sustainability training environments are required to achieve Sustainable Development UNESCO's goals [21]. The success of this challenge depends on effective cooperation among stakeholders at the national, regional and global levels [22]. Research studies on open innovation among universities and companies show that the main role of universities in innovation is to create new solutions, improve business performance [23], and transfer knowledge to contribute to regional development and economic growth [24]. More research studies are necessary to comprehend the relationship between the use of university research results (and intellectual property restrictions) in industrial innovation [25] and to channel this undertaking by means of virtual platforms that allow value creation, cost reduction and fast innovation commercialization [26]. Open and collaborative innovation is still an issue under research and, during a process of this nature, the goal is to seek ideas that may be more successful [27] (p. 85). Likewise [28], it is mentioned that safeguarding the development and introduction of inventions to the market (innovating as an implementation process) requires systematic approaches, such as project planning, participatory rural assessment or regional estimate. The fact of knowing which research studies have been conducted on open innovation may provide options for training frameworks aiming at promoting sustainable development.

In this sense, this paper aims to analyze the most recent empirical evidence published (2015-2018) regarding open innovation, focusing interest on identifying which research has been carried out in this area and in which categories, looking to detect its potential for sustainable training environments. To do so, a systematic mapping study was conducted on articles published from January 2015 to September 2018, following several analyzed methodologies [29-32]. This methodology works as a useful previous step of a Systematic Literature Review or a Meta-analysis, and it gives us a general view of the state of the art regarding open innovation. The document presents methodology, results, data analysis and finally, a conclusion that mentions opportunity areas for sustainable training frameworks and other ideas for future research. 


\section{Materials and Methods}

The Systematic Mapping Method comprises analyzing information to create a general view of a subject's area of study; it works as a previous step of analysis to a Systematic Literature Review or a Meta-analysis. The goal of Systematic Mapping is to classify, analyze and identify publication databases of scientific reports to find knowledge gaps. The topic analysis quantifies the number of publications. Therefore, the systematic mapping offers a structure regarding the type of scientific reports and its results [31]. This method helps to identify the state-of-the-art, to gather information about tendencies and identification of authors, journals and leading publications about the topic.

The methodological process of Systematic Mapping follows a protocol that includes some defined steps to work on scientific reports regarding the area of study. To conduct this study, several methodological ideas were considered in studies conducted by García-Peñalvo [29], Kitchenman et al. [30], Petersen [31], Velásquez-Duran and Ramirez-Montoya [32]. According to these authors, a research protocol has been outlined, which is illustrated in Figure 1.

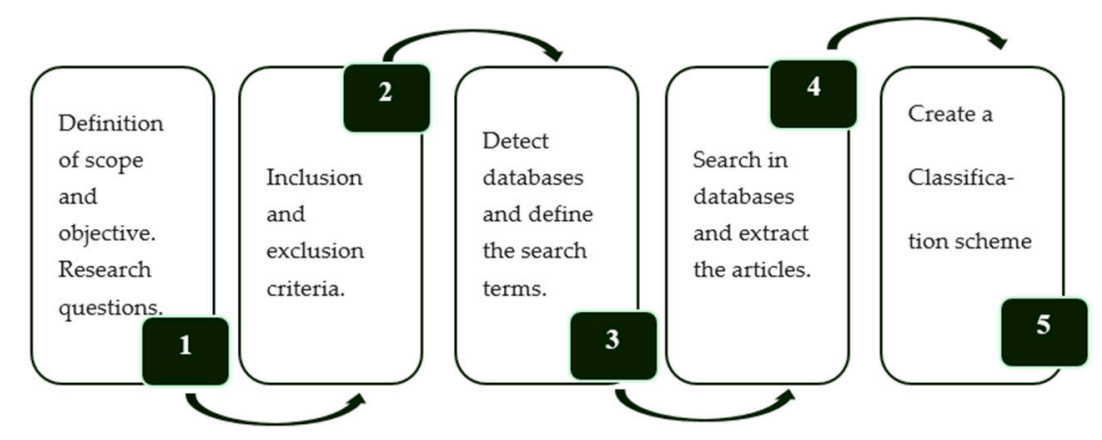

Figure 1. Defined protocol of the mapping methodological process (designed by the authors).

\subsection{Definition of Scope and Objective (Research Questions)}

The methodology follows the path marked by research questions. According to the work of Kitchenman et al. [30], the mapping begins with research questions that are answered by reviewing primary studies, and such questions are tabulated in categories. The methodology is planned according to the scope and objective of the research, which should indicate the opportunity to identify research gaps and opportunities for future research. To achieve this, questions are developed, and each step in the methodology is marked according to the cited authors. Table 1 shows the research questions developed for this study.

Table 1. Research questions.

\begin{tabular}{|c|c|}
\hline Question & Type of Response Sought \\
\hline $\begin{array}{l}\text { RQ1: How many studies are in the WOS and Scopus } \\
\text { databases from } 2015 \text { to } 2018 ?\end{array}$ & $\begin{array}{l}\text { Number of articles in Scopus } \\
\text { Number of articles in WOS } \\
\text { Number of duplicated articles } \\
\text { Number of theoretical-conceptual articles } \\
\text { Number of empirical scientific articles }\end{array}$ \\
\hline RQ2: Who are the authors of the most cited articles? & $\begin{array}{l}\text { Most cited authors } \\
\text { Most cited articles }\end{array}$ \\
\hline RQ3: What is the geographical distribution of the authors? & Countries where the authors are from \\
\hline RQ4: What are the journals with more publications on this & Journals \\
\hline line of research? & $\begin{array}{l}\text { Q1, Q2, Q3 or Q4 } \\
\text { Social }\end{array}$ \\
\hline RQ5: In what contexts are these studies developed? & $\begin{array}{l}\text { Empresarial } \\
\text { Cultural } \\
\text { Educational (Academic) }\end{array}$ \\
\hline $\begin{array}{l}\text { RQ6: What are the main topics addressed in this line of } \\
\text { research? }\end{array}$ & $\begin{array}{l}\text { Categories on emerging topics } \\
\text { Scientific production tendencies on the topics }\end{array}$ \\
\hline
\end{tabular}




\subsection{Inclusion and Exclusion Criteria}

The inclusion and exclusion criteria are used to exclude studies that are not relevant for answering the research questions. In the methodological steps followed by Kroll et al. [33], the relevance of excluding studies that reduce accuracy to the results is stated. It is necessary to define the criteria considering time, type of document, language, the relevance of the article's topic. For this study, the inclusion terms were as follows: studies on open innovation, articles published only on journals that can be found on two databases: Web of Science (WOS) and Scopus, articles published from January 2015 to September 2018, articles related with the educational sector (social sciences, phycology, multidisciplinary, sustainability, educational research). The exclusion criteria were the following: duplicated articles, the ESCI (Emerging Source Citation Index), books, book chapters and speeches, and the quality criteria covered indicators regarding the contribution of valuable information on open innovation and coherence between the objective, method, and results (Table 2).

Table 2. Inclusion, exclusion and quality criteria.

\begin{tabular}{|c|c|c|}
\hline Inclusion Criteria & Exclusion Criteria & Quality Criteria \\
\hline $\begin{array}{l}\text { Studies on open innovation in the } \\
\text { WOS and Scopus databases. }\end{array}$ & $\begin{array}{l}\text { Studies that do not address open } \\
\text { innovation. }\end{array}$ & $\begin{array}{l}\text { A contribution of valuable } \\
\text { information regarding open } \\
\text { innovation. }\end{array}$ \\
\hline Scientific articles. & $\begin{array}{l}\text { Speech documents, book chapters, } \\
\text { ESCI. }\end{array}$ & $\begin{array}{l}\text { Coherence between the objective, } \\
\text { method, and results. }\end{array}$ \\
\hline $\begin{array}{l}\text { Articles published in high-impact } \\
\text { journals. }\end{array}$ & $\begin{array}{c}\text { Articles that have not been } \\
\text { published in high-impact journals. }\end{array}$ & \\
\hline $\begin{array}{l}\text { Articles published during 2015- } \\
2018 .\end{array}$ & $\begin{array}{l}\text { Articles not published during } \\
\text { 2015-2018. }\end{array}$ & \\
\hline $\begin{array}{l}\text { Articles related to the training } \\
\text { field. }\end{array}$ & $\begin{array}{l}\text { Articles not related to the training } \\
\text { field. }\end{array}$ & \\
\hline $\begin{array}{c}\text { Articles on studies related to } \\
\text { sustainability. }\end{array}$ & & \\
\hline
\end{tabular}

\subsection{Identification of the Databases and Search Terms}

The databases used to make search queries are WOS and Scopus, this in order to review scientific reports which expose empirical evidence about open innovation. A search string was defined to be equally applied in both databases, according to the research questions and inclusion and exclusion criteria. Otherwise, the search results could not be comparable. To search the articles analyzed in this study, Boolean expressions were similarly used in both databases. The search strings used are shown in Table 3. As a possible risk assessment, it should be noted that the selection of the evidence of the articles was made with the selectivity method of the specified search chains, according to the area of interest for the article. The results of the selectivity were the basis for working the mapping review questions. 
Table 3. Search strings in Scopus and WOS.

\begin{tabular}{cc}
\hline Search String in Scopus & Search String in WOS \\
\hline & SUBJECT: ('open innovation') AND SUBJECT: ('educ' OR \\
& 'learning' OR 'competences' OR 'capacities' OR 'knowledge') \\
(TITLE-ABS-KEY ('Open innovation') AND & Refined by: TYPES OF DOCUMENTS: (ARTICLE) AND \\
TITLE-ABS-KEY (educ*) OR TITLE-ABS-KEY & PUBLICATION YEAR: (2018 OR 2017 OR 2016 OR 2015) AND \\
(knowledge) OR TITLE-ABS-KEY (capacities) OR & WEB OF SCIENCE CATEGORIES: (SOCIOLOGY OR \\
TITLE-ABS-KEY (competences) OR TITLE-ABS-KEY & COMMUNICATION OR PSYCHOLOGY APPLIED OR \\
(learning)) AND DOCTYPE (ar) AND PUBYEAR > & HUMANITIES MULTIDISCIPLINARY OR \\
2014 AND (LIMIT-TO (SUBJAREA, 'SOCI') OR & MULTIDISCIPLINARY SCIENCES OR ENERGY FUELS OR \\
LIMIT-TO (SUBJAREA, 'ENER') OR LIMIT-TO & GREEN SUSTAINABLE SCIENCE TECHNOLOGY OR \\
(SUBJAREA, 'PSYC') OR LIMIT-TO (SUBJAREA, & EDUCATION EDUCATIONAL RESEARCH OR SOCIAL \\
'MULT')) & SCIENCES INTERDISCIPLINARY OR PSYCHOLOGY \\
& MULTIDISCIPLINARY OR PSYCHOLOGY SOCIAL) \\
& Period of time: Last five years. Indices: BKCI-S, BKCI-SSH, \\
* Truncation symbol used to broaden the search (education, educational, educating, etc.).
\end{tabular}

\subsection{Extraction of the Articles through Database Searches}

In this step, the search for and extraction of articles was completed, which were placed in an Excel sheet. The search in databases produced 202 results in Scopus and 178 in WOS. Afterward, the filter of study areas for this review was applied (social sciences, phycology, multidisciplinary, sustainability, educational research), resulting in 59 articles from Scopus and 70 results from WOS, a total of 129 articles. Once the duplicates were eliminated, the database included 47 articles from Scopus and 70 articles from WOS. Then, a detailed review was conducted on the type of documents and four articles were eliminated, which corresponded to book chapters (WOS) and nine emerging journal publications (ESCI) in WOS. Finally, the database was composed of 104 articles in total, of which 47 were retrieved from Scopus and 57 from WOS (See Figure 2).

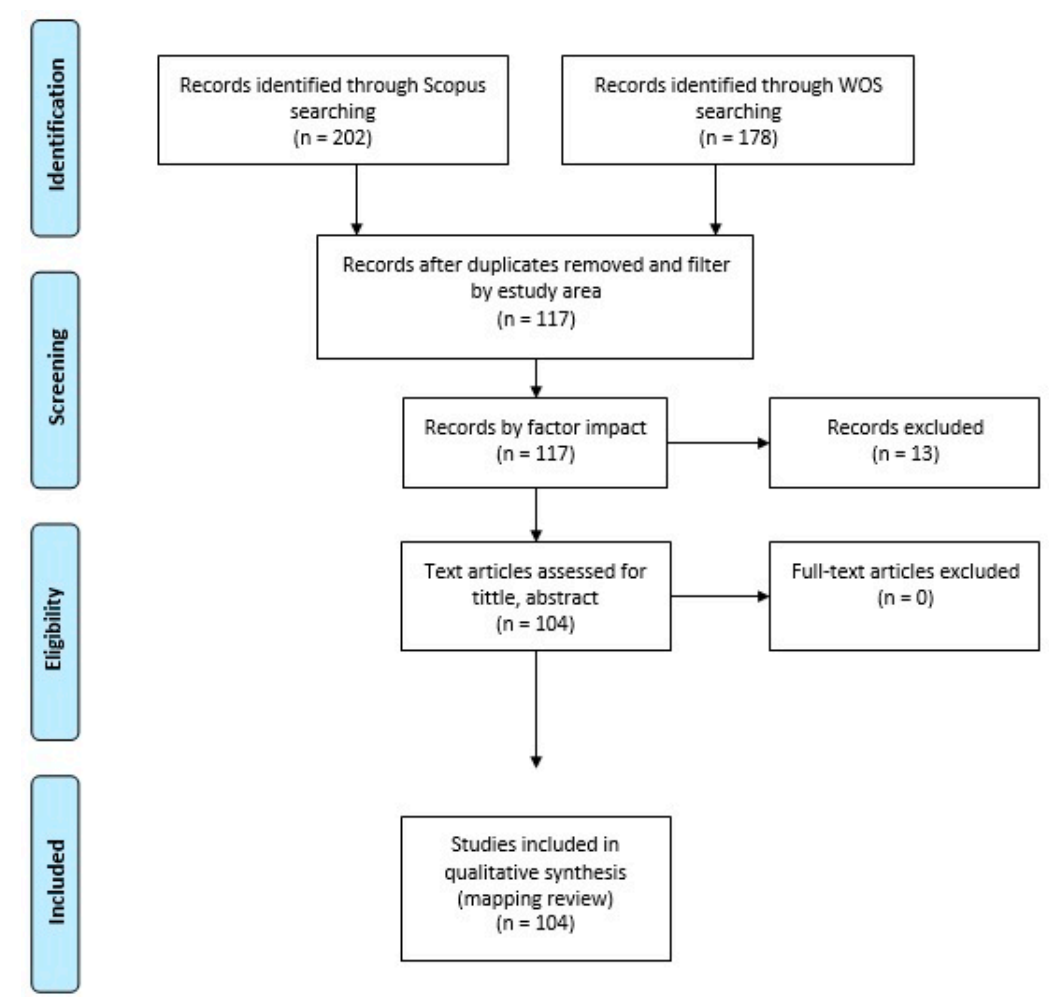

Figure 2. Review phases. 


\subsection{Creation of a Classification Scheme}

After searching for primary studies, the research protocol indicates reading and analyzing the abstract. According to the methodological steps that follow [34], from reading the abstract, introduction and conclusion in systematic reviews, a classification scheme is created. In this step, to understand the nature of the studies, keywords, concepts and research contexts are identified to create a classification scheme to classify the studies. In the case of this analysis, the articles' classification was conducted considering five categories created by the authors of this paper to discover potential training frameworks and to be in accordance with the research approach: (1) knowledge generation, (2) creation and development of products, (3) transference, (4) multidisciplinary and (5) collaborative. In Table 4 , a description of each of these categories is shown.

Table 4. Categories to review studies on open innovation (designed by the authors).

\begin{tabular}{cl}
\hline \multicolumn{1}{c}{ Categories } & \multicolumn{1}{c}{ Description } \\
\hline Knowledge generation & $\begin{array}{l}\text { Studies that mention trend research, approach on strategic areas, talent support for } \\
\text { research, intellectual property. }\end{array}$ \\
\hline $\begin{array}{c}\text { Creation and } \\
\text { development of } \\
\text { products }\end{array}$ & $\begin{array}{l}\text { Studies on new products or services, new centers, research centers, development of } \\
\text { ideas, people and companies, open innovation laboratories, venture and } \\
\text { transformation laboratory, makerspace collaborative design, products, community } \\
\text { innovation laboratory, public policies, community initiatives, social transformation } \\
\text { projects, operational specialization and customer involvement in product creation. }\end{array}$ \\
\hline \multirow{2}{*}{$\begin{array}{c}\text { Transference } \\
\text { Multidisciplinary }\end{array}$} & $\begin{array}{l}\text { Studies related to contributions to companies, the government, NGOs, educational } \\
\text { institutions and society, capital, professionals, start-ups, business innovation, } \\
\text { business models, innovation in government and society, the link between } \\
\text { companies and universities, social impact. }\end{array}$ \\
& $\begin{array}{l}\text { Studies related to methodologies on open resources for the development of } \\
\text { software, involvement in several disciplines, external developers: (a) suppliers and } \\
\text { customers, (b) universities, the government and private laboratories, (c) } \\
\text { competitors, (d) other countries. }\end{array}$ \\
\hline \multirow{2}{*}{$\begin{array}{l}\text { Studies stating the co-construction of knowledge, which alters the subjects and } \\
\text { disciplines involved, as well as the new knowledge diffusion tools, collaboration } \\
\text { networks among subjects, internal agents, suppliers, customers, competitors, } \\
\text { consultants and universities, networking. }\end{array}$} \\
\hline
\end{tabular}

\section{Results}

The mapping methodological process was applied, creating an Excel database. In this file, the articles and metadata needed to answer the research questions as well as to illustrate the results were organized.

This database can be accessed at the following link (see Appendix A): https:/ / docs.google.com/ spreadsheets/d/10TqZHxK1IpivmOlBhtzLfIqVT2ghC88fXM4wtZ_9Uu4/edit?usp=sharing.

\subsection{RQ1 How Many Studies Are in the WOS and Scopus Databases from 2015 to 2018?}

A total of 104 articles were obtained. Afterward, the abstracts of all articles were reviewed to determine the kind of methodology used, whether empirical or theoretical-contextual. This showed that $56(54 \%)$ studies follow an empirical methodology, of which 27 were obtained in Scopus and 29 in WOS; on the other hand, 48 (46\%) studies follow a theoretical-conceptual methodology, of which 20 were obtained from Scopus and 28 from WOS (see Figure 3). 


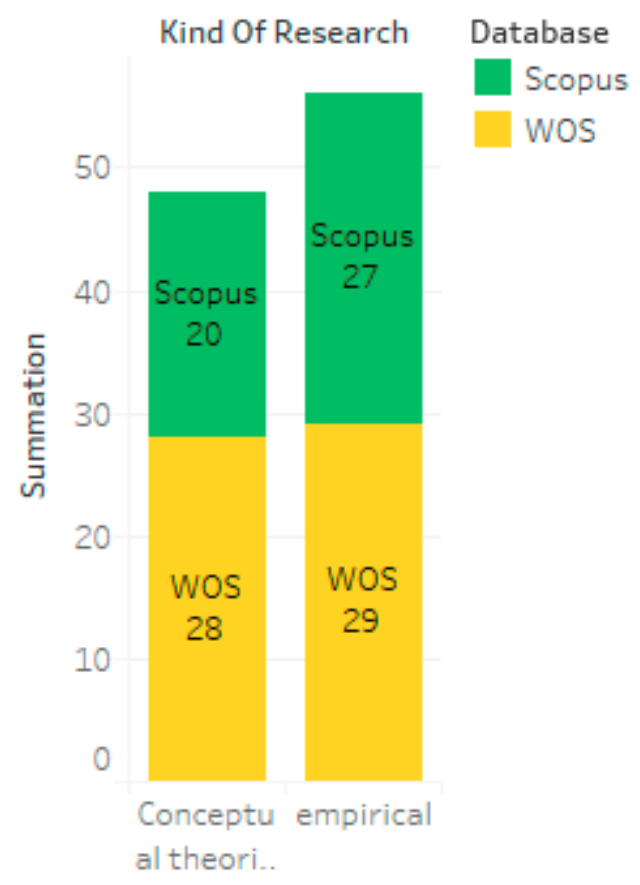

Figure 3. Number of articles according to the kind of methodology.

\subsection{RQ2: Who Are the Most Cited Authors?}

The results indicate that the study that has been cited the most (i.e., 34 times) is related to research on integrated innovation in the user sustainable LivingLabs. In Table 5, the articles ordered by identification number and the number of times that each of them has been cited is shown.

Table 5. Most cited authors and articles (author's design).

\begin{tabular}{cc}
\hline Number of Citations & Cited Articles \\
\hline 34 & 100 \\
18 & 83 \\
17 & 67 \\
16 & 60 \\
14 & 50 \\
13 & 45. \\
10 & $8,63$. \\
9 & $11,72,77$. \\
7 & $36,41$. \\
6 & 90. \\
5 & $5,26,29,35,65,81,87,102$. \\
4 & $6,15,56,76,82$. \\
2 & $25,47,54,62,98$. \\
1 & $49,57,61,69$. \\
0 & $12,21,38,44,46,59,66,84,85,95,96,99$. \\
& $3,22,27,28,30,33,34,51,52,64,68,71,78,91,92,104$. \\
& $79,80,86,88,89,93,94,97,101$. \\
\hline
\end{tabular}

Likewise, a histogram is shown (Figure 4), which represents the frequency of cited articles. For this histogram, a maximum (34) and a minimum (0) number of citations were considered, and to illustrate it, the following intervals were categorized: $0,1-5,5-10,10-15,15-20,20-25,25-30$ and 30-35. As shown in Figure 4, most articles have been cited between 0 and 5 times, and from there, 19 articles were cited between 5 and 10 times, 5 articles were cited between 10 and 15 times, 3 articles were cited between 15 and 20 times, and 1 article was cited between 30 and 35 times. These articles have been previously displayed in Table 5. 


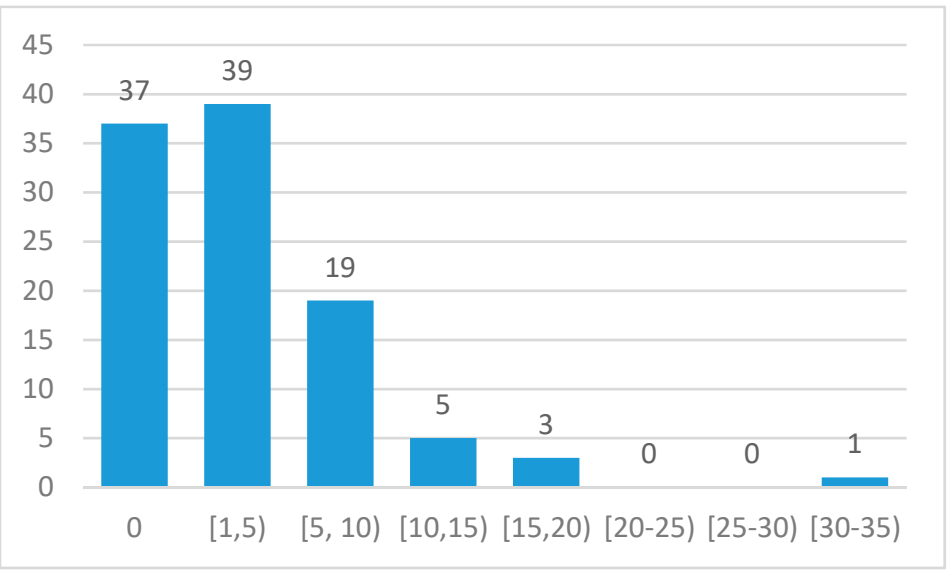

Figure 4. Frequency of cited articles according to intervals.

\subsection{RQ3: What Is the Geographical Distribution of the Authors?}

According to the geographical distribution of the authors (considering the first author of the publication), articles on open innovation were most frequently published in Italy, with 15 published articles in total, followed by South Korea and Spain, with 11 and 10 publications, respectively. The United States had seven articles, Germany had six and China and Russia had five each. The geographical distribution map is shown in Figure 5. In the same manner, in Figure 6, the frequency of studies published according to the country can be seen.

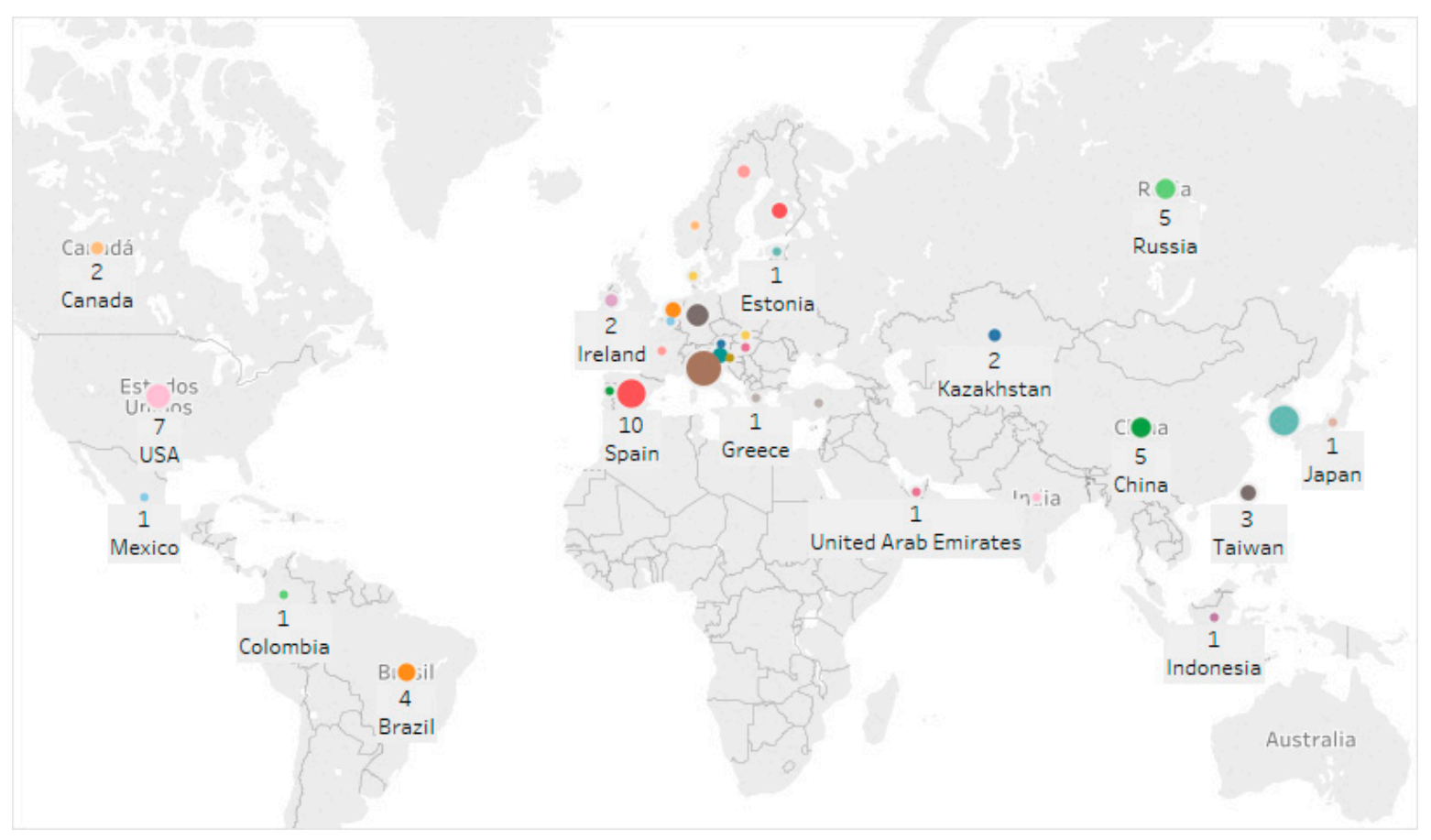

Figure 5. Geographical distribution of authors. 


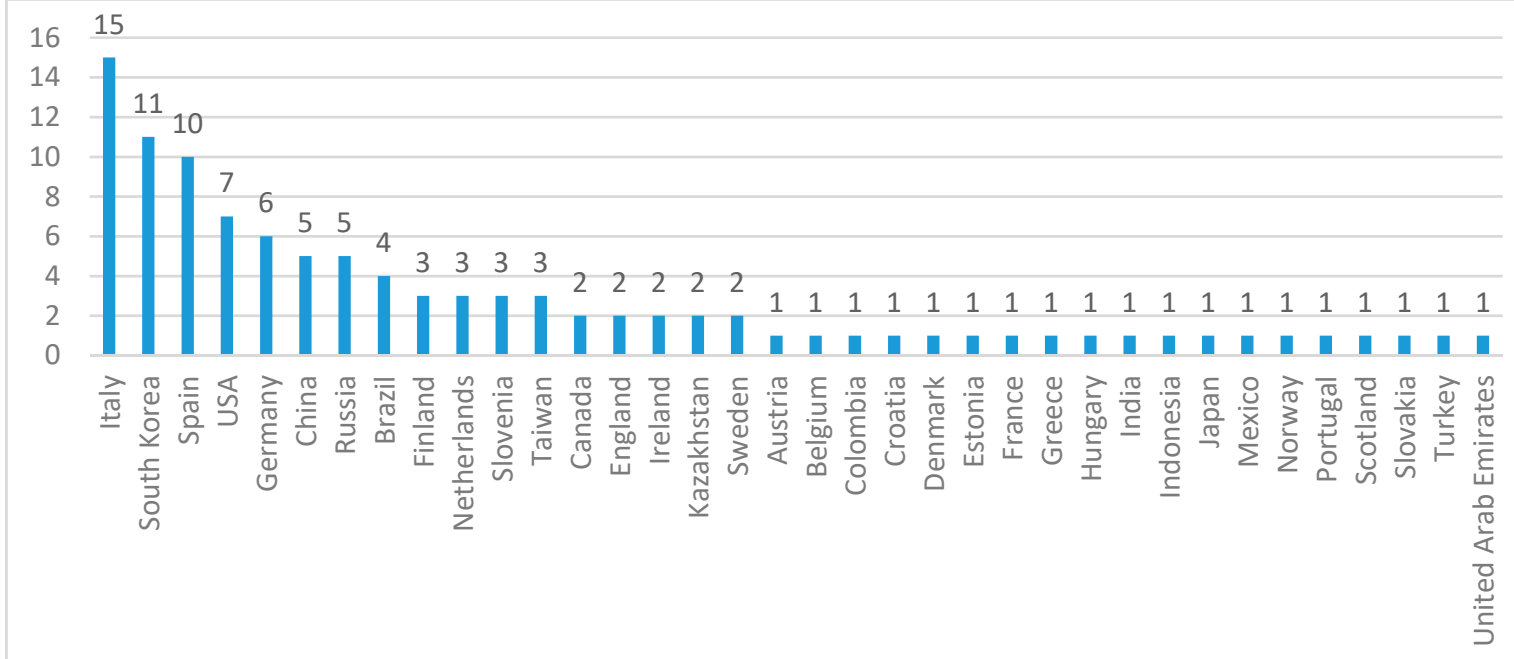

Figure 6. Frequency of publications according to country.

\subsection{RQ4: What Are the Journals with More Publications on This Line of Research?}

The journals with more articles published on open innovation are shown in Table 6, which also shows the database where the articles are indexed, the quartile, the number of articles per journal and the identification number of each article. Likewise, in Figure 7, proportional representation of the studies published in journals can be seen, Q1 (Green), Q2 (yellow), Q3 (orange) and Q4 (red). In this figure, the most published fields of study in journals according to their quartile are shown.

Table 6. Journals with more than two published articles.

\begin{tabular}{|c|c|c|c|c|}
\hline Journal & Database & Quartile & $\begin{array}{l}\text { Number of } \\
\text { Articles }\end{array}$ & $\begin{array}{c}\text { Article Identification } \\
\text { Number }\end{array}$ \\
\hline $\begin{array}{c}\text { Technology Analysis \& Strategic } \\
\text { Management }\end{array}$ & WOS & Q3 & 17 & $\begin{array}{r}103,11.41,26,87,6,15,21,38, \\
66,27,33,52,68,20,86,93 .\end{array}$ \\
\hline Sustainability & WOS-Scopus & Q2 & 13 & $25,47,49,59,96,9,22,51$ \\
\hline $\begin{array}{c}\text { Technological Forecasting and Social } \\
\text { Change }\end{array}$ & Scopus & Q1 & 8 & $67,50,90,29,35,2,91,7$ \\
\hline Journal of Cleaner Production & WOS-Scopus & Q1 & 7 & $100,8,81,85,28,34,13$ \\
\hline Government Information Quarterly & Scopus & Q1 & 3 & $83,102,78$ \\
\hline Economy of Region & Scopus & Q2 & 2 & 98,40 \\
\hline Group Decision and Negotiation & WOS & Q3 & 2 & 46,48 . \\
\hline Industry and Higher Education & WOS & Q3 & 2 & 3,18 \\
\hline Información Tecnológica & Scopus & Q3 & 2 & 62,57 . \\
\hline $\begin{array}{c}\text { International Journal of Technology } \\
\text { Management }\end{array}$ & Scopus & Q2 & 2 & $10,97$. \\
\hline Technology in Society & WOS-Scopus & Q2 & 2 & 74,101 \\
\hline
\end{tabular}

In the same way, Table 7 shows the journal distribution according to the quartile level (Q1, Q2, Q3, Q4) wherein studies on open innovation are published.

Table 7. Articles published in journals Q1, Q2, Q3 and Q4.

\begin{tabular}{|c|c|c|}
\hline Quartile & Articles & Total \\
\hline Q1 & $\begin{array}{l}100,83,67,60,50,45,8,36,90,29,35,81,102,56,76,61,84,85,99,1,2,28,34,78,91,7,13 \\
19,32,48,70,75,89 .\end{array}$ & 33 \\
\hline Q2 & $63,72,5,82,25,47,98,49,69,59,96,9,22,51,10,14,23,24,31,40,42,43,53,74,79,94,97$ & 27 \\
\hline Q3 & $\begin{array}{l}103,11,77,41,26,65,87,6,15,62,57,12,21,38,46,66 \\
95,27,30,33,52,68,92,3,18,20,37,58,73,80,86,88,93\end{array}$ & 33 \\
\hline Q4 & $54,44,64,71,104,4,16,17,39,55,101$ & 11 \\
\hline
\end{tabular}




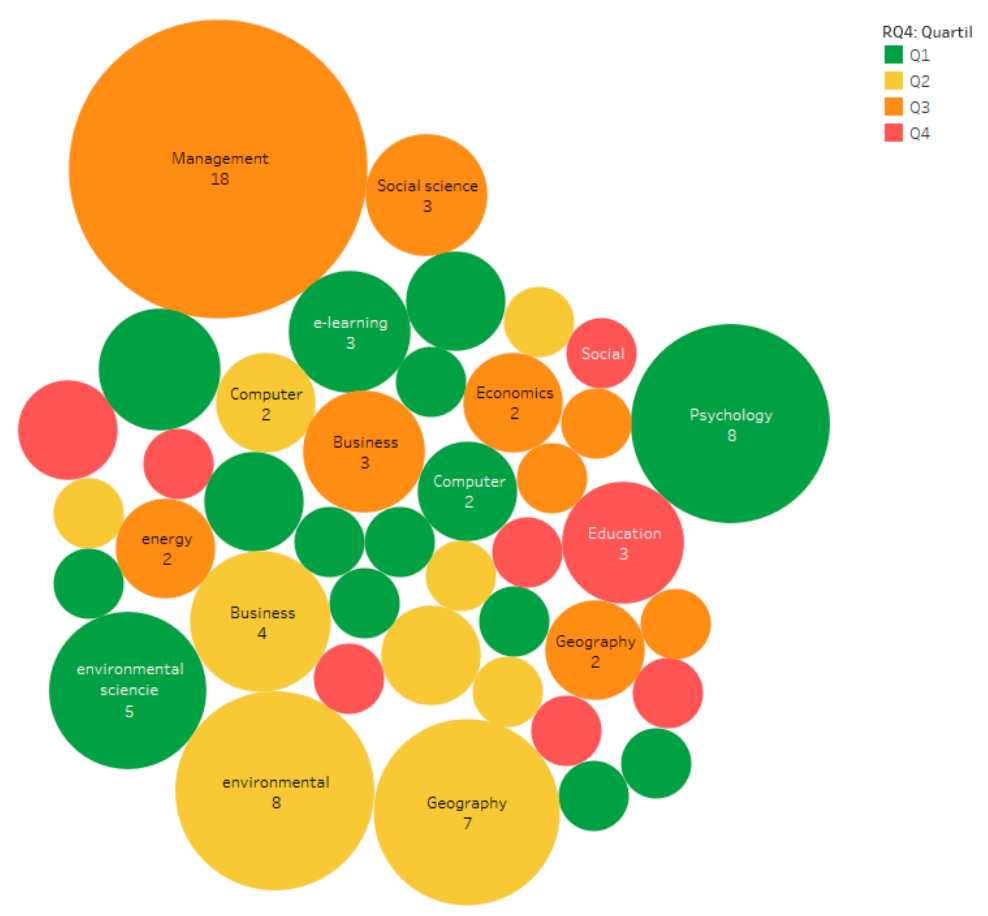

Figure 7. Predominant field of study according to the level of impact (quartile).

\subsection{RQ5: In What Contexts Are These Studies Developed?}

This question is answered with the aim of understanding the context in which the research was conducted. In this mapping (Figure 8), 49 studies were carried out in the business context, 40 in the social context, 5 in the cultural context and 10 in the educational context (9 were carried out at the higher education level and 1 at the elementary school level).

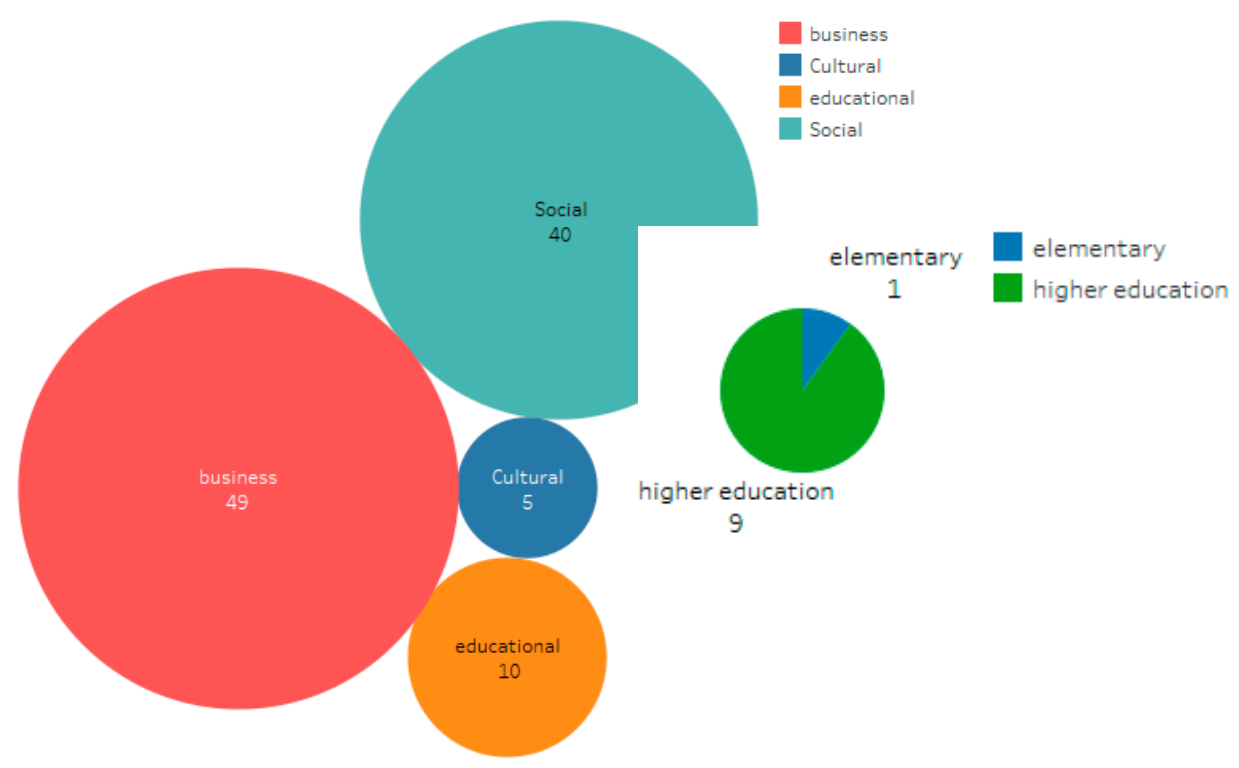

Figure 8. Context in which the studies were carried out.

\subsection{RQ5: What Are the Main Topics Addressed in This Line of Research?}

To answer this question, analysis regarding the topics addressed in the contexts was conducted. For this analysis, a specific approach was determined for the applied methodology and five categories were established: 41 articles were found with the knowledge generation approach, 22 with the creation 
and development of products approach, 18 with the transference approach, 15 with the collaborative approach and eight with the multidisciplinary approach.

In Figure 9, these approaches related to the context of the studies analyzed can be seen. The graph shows that the knowledge generation approach (red) is addressed most often in studies carried out in the business context; then, in the creation and development of products approach the social context stands out; in the collaborative approach, the business context is more recurrent; in the transference approach, studies carried out in business contexts are more common, and lastly, in the multidisciplinary approach, the social context prevails. In this way, the studies carried out in educational contexts, which is the scope of this systematic mapping, are the least commonly addressed in the five categories of study approaches.

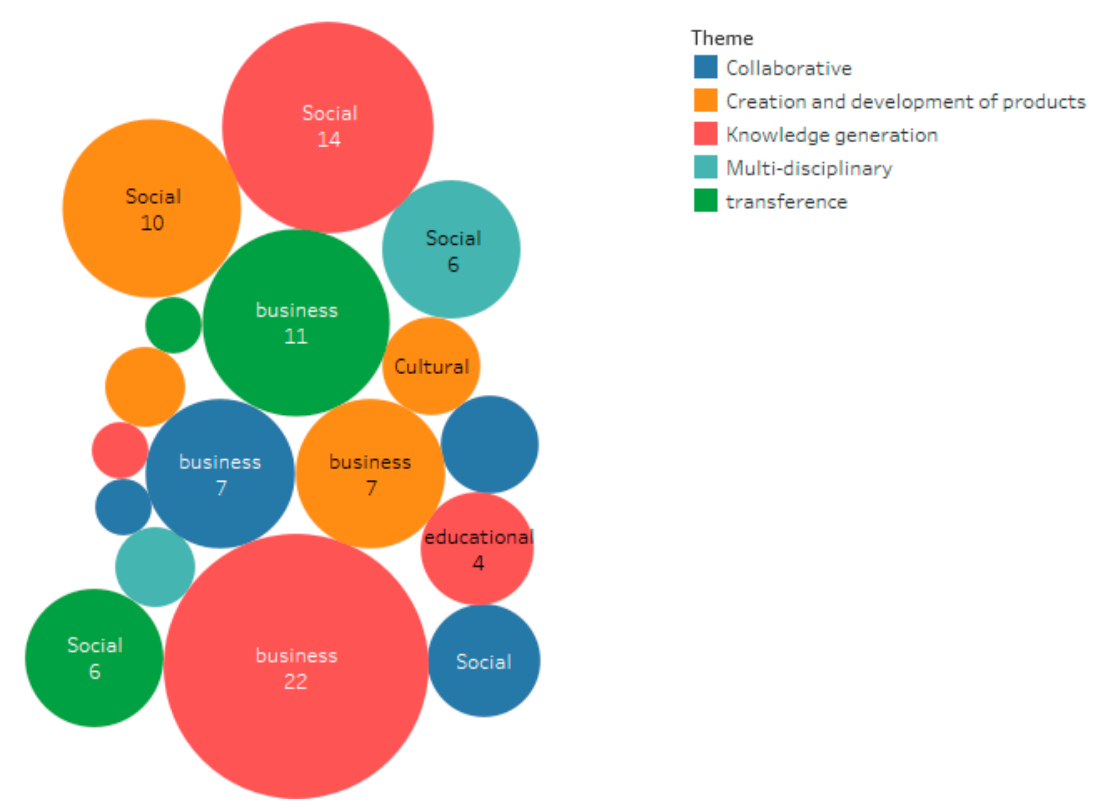

Figure 9. Main topics addressed in study contexts.

\section{Discussion}

Recent scientific research related to open innovation is inclined to maintain a balance between empirical and conceptual studies. In the WOS and Scopus databases, several studies addressing different perspectives and methodologies on open innovation (Figure 3) can be identified, and it is interesting to note that in the educational field, publications are still scarce, even though educational institutions are the principal knowledge generation organizations. (Figure 8). According to the OECD [2], this innovation model is dynamic and is based on knowledge; and, in this context, universities play a central role in creating new solutions [23] to regional development [24]. In this way, knowledge generation on current open innovation is, on the one hand, oriented towards the theoretical-conceptual explanation. On the other hand, it systematizes the experiences of this model's application in different contexts. This context encourages knowledge generation organizations to support the sustainable training experiences framework, where publication on open innovation should be encouraged.

High-impact scientific research regarding open innovation addresses the topic as an interdisciplinary method to solve global problems. In this study, we found that the most cited articles address the need for trans-disciplinary research, its benefits to improve services and operations, research performance analysis and internal development and external knowledge, as well as external agents' involvement in solving problems (Table 5 and Figure 4). These topics are supported in what has been stated by Chesbrough [7] and Laine [8] regarding innovation and taking advantage of internal and external processes, in addition to the demand for interdisciplinary innovation 
networks [15-17]. The abovementioned studies indicate that taking advantage of internal and external sources of organizations allows the possibility of creating innovative solutions before several challenges. In the context of sustainable training environments, it is essential to integrate the collaborative and multidisciplinary view, in order to accumulate useful and different sources of knowledge to achieve interesting results on open innovation.

In the context of sustainable training environments, it is essential to integrate the collaborative and multidisciplinary view in order to accumulate useful and different sources of knowledge to achieve interesting results on open innovation.

High-impact journals that publish studies related to open innovation seek to spread scientific knowledge that covers topics including innovation, development and the interaction of social agents. Table 6 shows the journals that have published two or more articles related to this subject, which are focused on technology, science, sustainable and economic development and the relationship between company, industry, university, government, and business. These results show intersection points regarding the possibilities provided by the open innovation paradigm, such as creating and using technology, by means of input and output of knowledge to improve innovative and interactive capacities and to expand markets [3-6]. Studies on open innovation indicate that this has an impact on sustainable, social and economic development in society, where, undoubtedly, the educational field can contribute significantly.

Open innovation is not widely addressed in academic (educational) and cultural contexts. Figure 8 shows that there is a research trend towards business and social fields, but also that open innovation has been scarcely addressed in academic and cultural contexts. Regarding Fabrizio's study [25], more scientific research is required to understand the relationship between the use of results from university research and industrial innovation; additionally, West et al. [12] indicate the need to increase collaboration in entities such as universities, companies and governments. The abovementioned studies indicate that it is necessary to address studies on academic (educational) contexts which generate knowledge valuable for the development of internal and external agents.

More studies on open innovation are required in the transference, multidisciplinary and collaborative approaches. This is due to the obtained results, that show that most of the studies deal with knowledge generation and the multidisciplinary field is less addressed (Figure 9). In this regard, it is understood that open innovation is co-produced and that the results represent an intellectual capital that is translated into value, which can be commercialized by means of virtual platforms $[10,11,13,26]$. According to this, we can conclude that it is necessary to generate more knowledge on innovation topics within the government, society, companies and universities, interdisciplinary involvement and activities oriented towards co-construction and collaboration. Certainly, e-learning, b-learning, m-learning and, multi-modal environments may be the driving force to enrich sustainable training environments.

This study aimed to analyze the empirical evidence published on open innovation in the last three years (2015-2018). From this analysis, it can be noted that there is a need to research academic and cultural contexts, additionally, it would be desirable to undertake research projects in geographic contexts other than most frequent ones (Figure 6), and to review additional evidence beyond the databases consulted in this study. It would be interesting to conduct further studies on innovation that include collaborative work among universities and companies because universities have an important role in generating new solutions and business performance. In addition, open innovation results are essential for regional development and economic growth [23,24]. Similarly, the different educational levels and ongoing education may be revitalizing frameworks connecting society, companies, NGOs and, society in general.

To conclude, this paper presents a view of challenges that invites scientific research of the possibilities arising from the paradigm application of open innovation in academic (educational) context, which is recognized as an important agent in open innovation processes, for example, the development of sustainable training environments. According to UNESCO [21,22], sustainability 
represents a challenge to create quality environments with the cooperation of different agents. This leads to questioning the ways in which internal and external agents may be involved in solving problems and thinking about how the connection and collaborative and interdisciplinary work between educational institutions, companies and the government may help with sustainable development in communities. These results come to expose practical implications for developers of educational policies and linking university-business-government. However, some limitations should be acknowledged; among them, the articles analyzed were searched only in the Scopus and WOS databases, and the results were limited to the sub-areas mentioned in Table 3. This paper works as a basis for future research which deeply explores the contributions of open innovation in sustainable training environments.

Author Contributions: In this research, both authors substantially established and contributed to the approach of this study. M.-S.R.-M. greatly contributed to the conceptualization, literature review, guidelines for the methodology and review of style and writing, whereas A.G.-G. greatly contributed to the organization and analysis of the research data. Both authors contributed to the discussion of results.

Funding: This work is the result of project funding by CONACYT-SENER (Mexico) through the 'Binational Laboratory for Intelligent Management of Energetic Sustainability and Technological Formation' project (Ref. 266632).

Acknowledgments: Special thanks to García-Peñalvo and González-Pérez for their methodological contributions.

Conflicts of Interest: The authors declare no conflict of interest.

\section{Appendix A}

Access link to the database created for the analysis of the literature systematic mapping https://docs.google.com/spreadsheets/d/10TqZHxK1IpivmOlBhtzLfIqVT2ghC88fXM4wtZ_ 9Uu4/edit?usp=sharing.

\section{References}

1. UNESCO. Transforming our world: The 2030 agenda for sustainable development. In Proceedings of the Resolution adopted by the General Assembly, Paris, France, 25 September 2015.

2. OECD. Open Innovation in Global Networks; OECD Publications: Paris, France, 2008; pp. 1-5. ISBN 978-92-64-04767-9.

3. Greco, M.; Grimaldi, M.; Cricelli, L. Open innovation actions and innovations performance. Eur. J. Innov. Manag. 2013, 18, 150-171. [CrossRef]

4. Chesbrough, H. Open innovation: A new paradigm for understanding industrial innovation. In Open Innovation Researching a New Paradigm, 2nd ed.; Chesbrough, H., Vanhaverbeke, W., West, J., Eds.; Oxford University Press: Oxford, UK, 2008; Volume 2, pp. 21-33. ISBN 978-0-19-929072-7.

5. Gassmann, O.; Enkel, E.; Chesbrough, H. The future of open innovation. R. Manag. 2010, 40, 213-221. [CrossRef]

6. Remon, D. Innovation ouverte et capacités dynamiques: Préparation à la collaboration internationale des PME. Innovations 2012, 3, 71-98. [CrossRef]

7. Chesbrough, H. Open innovation: Where we've been and where we're going. Res. Technol. Manag. 2012, 55, 20-27. [CrossRef]

8. Laine, K.; Leino, M.; Pulkkinen, P. Open innovation between higher education and industry. J. Knowl. Econ. 2015, 6, 589-610. [CrossRef]

9. Obea Research Group. Innovación Abierta, Más Allá de la Innovación Tradicional, 1st ed.; Mondragon Unibertsitatea: Mondragón, Spain, 2009; pp. 32-54.

10. Loilier, T.; Tellier, A. Que faire du modèle de l'innovation ouverte? J. Fr. Manag. 2011, 1, 69-85. [CrossRef]

11. Ramírez-Montoya, M.S.; García-Peñalvo, F.J. Co-creation and open innovation: Systematic literature review. Comunicar 2018, 26, 9-18. [CrossRef]

12. West, J.; Salter, A.; Vanhaverbeke, W.; Chesbrough, H. Open innovation: The next decade. Res. Policy 2014, 43, 805-811. [CrossRef]

13. Užienè, L. Open Innovation, Knowledge Flows and Intellectual Capital. Proc. Soc. Behav. Sci. 2015, 213, 1057-1062. [CrossRef] 
14. Calderón, M.G. El valor estratégico de los acuerdos de colaboración para la adquisición de conocimiento en innovación abierta. Un análisis del sector de las TIC en España. Cdor. Y Adom. 2010, 55, 41-64. Available online: http:/ / www.scielo.org.mx/scielo.php?script=sci_arttext\&pid=S0186-10422010000300003\&lng=en\& tlng=en (accessed on 7 February 2019).

15. Muñoz, M.; Santoyo, V.H. Del extensionismo a las redes de innovación. In Del Extensionismo Agrícola a las Redes de Innovación Rural, 1st ed.; Santoyo, V.H., Ed.; Universidad Autónoma Chapingo: Ciudad de México, México, 2010; pp. 31-71. ISBN 978-607-12-0143-0.

16. Rey, G.A. Hibridación, globalización y redes sociales: 'cazar conexiones' es el nuevo reto de los temas de vigilancia y gestión del conocimiento. In Proceedings of the Visio, San Sebastían, España, 18-19 October 2007; Available online: https:/ / amaliorey.com/wp-content/uploads/2008/12/hibridacion-globalizaciony-redes-sociales-impacto-en-los-sistemas-de-vt-y-gc-conferencia-visio1.pdf (accessed on 7 February 2019).

17. Bergema, K.; Kleinsmann, M.; Valkenburg, R. Exploring collaboration in a networked innovation project in industry. In Proceedings of the 18th International Conference on Engineering Design (ICED 11), Impacting Society through Engineering Design Design Organisation and Management, Copenhagen, Denmark, 15-19 August 2011; Available online: https://www.designsociety.org/publication/30509/ exploring_collaboration_in_a_networked_innovation_project_in_industry (accessed on 4 November 2018).

18. Fay, D.; Borril, C.; Amir, Z.; Haward, R.; West, M.A. Getting the most out of multidisciplinary teams: A multi-sample study of team innovation in health care. J. Occup. Organ. Psychol. 2006, 1, 553-567. [CrossRef]

19. Thompson, M.J.R. Social capital, innovation and economic growth. Nipe Work. Pap. Ser. 2015, 3, 1-24. [CrossRef]

20. Buyurgan, N.; Meixell, M.J. Educational innovation and reform in the decision sciences: An introduction to the special issue on multidisciplinary and collaborative practices. Dec. Sci. J. Innov. Educ. 2015, 1, 115-119. [CrossRef]

21. UNESCO. La UNESCO Avanza La Agenda 2030 para el Desarrollo Sostenible. Paris, France, 2017. Available online: http:/ / www.unesco.org/new / fileadmin/MULTIMEDIA/FIELD/Hanoi/2030_Brochure_SP.pdf (accessed on 23 January 2019).

22. Bokova, I.G. Estrategia de educación de la UNESCO, 2014-2021. Paris, France, 2014. Available online: https:/ / unesdoc.unesco.org/ark:/48223/pf0000231288 (accessed on 23 January 2019).

23. Al-Ashaab, A.; Flores, M.; Doultsinou, A.; Magyar, A. A balanced scorecard for measuring the impact of industry-university collaboration. Prod. Plan. Control 2011, 22, 554-570. [CrossRef]

24. León, G.; Martínez, R.Q. How Can a University Drive an Open Innovation Ecosystem? Technol. Innov. Manag. Rev. 2016, 6, 48-51. [CrossRef]

25. Fabrizio, K.R. The use of university research in firm innovation. In Open Innovation Researching a New Paradigm, 2nd ed.; Chesbrough, H., Vanhaverbeke, W., West, J., Eds.; Oxford University Press: Oxford, UK, 2008; Volume 2, pp. 33-160. ISBN 978-0-19-929072-7.

26. Nambisan, S.; Siegel, D.; Kenney, M. On open innovation, platforms, and entrepreneurship. Strateg. Entrep. J. 2018, 12, 354-368. [CrossRef]

27. Pablos, C.; Soret, I.; Lopez, M. Un Modelo de Medición de Resultados en las Prácticas de Innovación Abierta. J. Technol. Manag. Innov. 2013, 8, 84-92. [CrossRef]

28. Schwerdtner, W.; Siebert, R.; Busse, M.; Freisinger, U.B. Regional open innovation roadmapping: A new framework for innovation-based regional development. Sustainability 2015, 7, 2301-2321. [CrossRef]

29. García-Peñalvo, F.J. Mapeos Sistemáticos de Literatura, Revisiones Sistemáticas de Literatura y Benchmarking de Programas Formativos; Grupo GRIAL: Salamanca, España; Available online: https:/ / repositorio.grial.eu/ handle/grial/1056 (accessed on 7 February 2019). [CrossRef]

30. Kitchenman, B.; Pretorius, R.; Budgen, O.; Breneton, O.P.; Turner, M.; Niazi, M.; Linkman, S. Systematic literature reviews in software engineering-A tertiary study. Inf. Softw. Technol. 2010, 52, 792-805. [CrossRef]

31. Petersen, K.; Feldt, R.; Mujtaba, S.; Mattsson, M. Systematic Mapping Studies in Software Engineering. EASE 2008, 8, 68-77. Available online: https:/ / www.researchgate.net/profile/Michael_Mattsson/publication/ 228350426_Systematic_Mapping_Studies_in_Software_Engineering/links/54d0a8e90cf20323c218713d/ Systematic-Mapping-Studies-in-Software-Engineering.pdf (accessed on 7 February 2019).

32. Velásquez-Duran, A.; Ramirez-Montoya, M.S. Research management systems: Systematic mapping of literature. Int. J. Adv. Sci. Eng. Inf. Technol. 2018, 8, 44-55. [CrossRef] 
33. Kroll, J.; Richardson, I.; Prikladnicki, R.; Audy, L.N.J. Empirical evidence in follow the sun software development: A systematic mapping study. Inf. Softw. Technol. 2017, 93, 30-44. [CrossRef]

34. Seaman, K.; Dzidic, P.L.; Castell, E.; Saunders, C.; Breen, L.J. A systematic review of women's knowledge of screening mammography. Breast 2018, 42, 81-93. [CrossRef] [PubMed] 